\title{
Leander manningi, a new palaemonine shrimp from Western Australia (Crustacea, Decapoda, Palaemonidae), with a review of the Indo-West Pacific species of the genus Leander E. Desmarest, 1849
}

\author{
A. J. Bruce \\ Queensland Museum, P.O. Box 3300, South Brisbane, Queensland, 4101 Australia \\ e-mail: abruce@broad.net.au
}

\begin{abstract}
A new species of marine palaemonine shrimp from Western Australia is described and illustrated. Leander manningi, a shrimp closely related to L. paulensis (Ortmann, 1897) and L. tenuicornis (Say, 1818), was collected during the course of a survey of Cockburn Sound, Western Australia. The Indo-West Pacific species of the genus Leander Desmarest, 1849 now known are reviewed and a key for their identification is provided.
\end{abstract}

\section{INTRODUCTION}

The first species of the small palaemonine genus Leander to enter the scientific record was Palaemon tenuicornis described by Say in 1819 from the North Atlantic Newfoundland Banks. It was re-described as Leander erraticus by Desmarest (1849) and first reported from the Indo-West Pacific region, from Japan, by De Haan (1849), as Palaemon latirostris. The species was formally placed in the genus Leander, as L. tenuicornis by Kingsley (1878). Kemp (1925) mentions that, in the Atlantic Ocean, the species occurs as far south as the Falkland Islands. It has since been commonly found throughout the warm waters of the world except for the Eastern Pacific region. The second species to be described was Leander paulensis Ortmann, 1897, from Brazil, and half a century later a third, L. kempi was described by Holthuis (1950b) from Indonesian waters. More recently, L. plumosus has been described from the Maldive Islands (Bruce, 1994) and since been found to occur in Indonesian, Japanese and New Caledonian seas. A strikingly coloured species, it contrasts markedly with the dull cryptically coloured $L$. tenuicomis and $L$. paulensis. The life colour pattern of $L$. kempi has not been recorded. A further species from Western Australia is now described and illustrated. Two species are now known to occur in Australian waters.

Abbreviations used: $\mathrm{CL}$, postorbital carapace length; BMNH, The Natural History Museum, London, U.K.; NTM, Northern Territory Museum, Darwin, Australia; RMNH, National Natural History Museum, Leiden, the Netherlands; WAM, Western Australian Museum, Perth, Western Australia; ZMA, Zoology Museum, University of Amsterdam, the Netherlands.

\section{SYSTEMATICS}

Leander manningi sp. nov.

Figures 1-4

\section{Material Examined}

Australia: Western Australia: 1 female, holotype, BP Oil Refinery Jetty, Kwinana, Cockburn Sound, 0.5m MLW, 11 May 1999, WAM C28204. 2 males paratypes, 1 juvenile male paratype, 1 , WAM C28205, 1 female, idem, 7.0m, 1 May 1999, WAM C28206.

\section{Diagnosis}

Rostrum moderately deep, far exceeding antennular peduncle, about 1.4 times $\mathrm{CL}$; dentition $2+7 / 5-6$; carapace and abdomen non-setose; third abdominal tergite not posteriorly produced, pleura of fourth segment posteroventrally rounded, fifth acute; stylocerite short, to half length of proximal segment of antennular peduncle; distolateral margin subrectangular, not concave; lamella of scaphocerite well exceeding distolateral tooth; mandibular palp 3-segmented; second pereiopod with chela longer than carpus, fingers distinctly shorter than palm, each with small acute proximal denticle, carpus longer than merus; merus and carpus unarmed; third pereiopod dactyl stout, about 0.4 of propod length, ventral margin almost straight; propod strongly spinulate.

\section{Description}

Small sized palaemonid shrimp, of slender form and with glabrous body.

Rostrum (Figure 1B)

About 1.3 times CL, well exceeding distal 

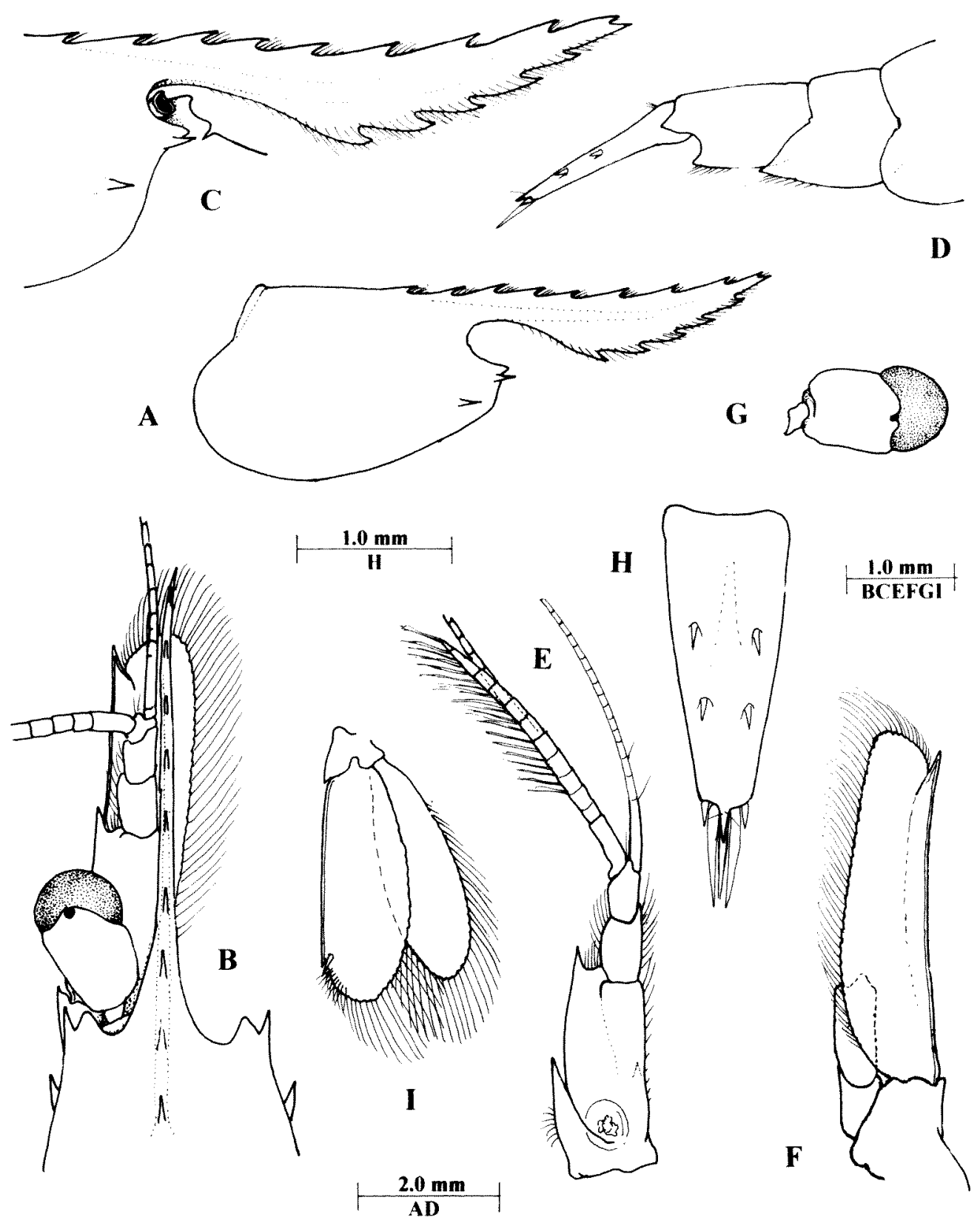

Figure 1 Leander manningi sp. nov., female holotype, Cockburn Sound, C28204. A, carapace and rostrum B, anterior carapace and rostrum, dorsal view. C, anterior carapace, rostrum and ophthalmic somite, lateral view. D, fifth and sixth abdominal segments, and telson. E, antennule. F, antenna. G, eye, dorsal. H, telson. I, uropod.

scaphocerite (Figure 1C), with well developed dorsal carina and deep ventral carina, feeble lateral carinae, slightly up-turned distally, dorsal margin with 9 similar acute teeth, first 2 situated on carapace, each with short row of small plumose setae distally, lower margin with 5-6 teeth larger than dorsal teeth, curved, with double row of submarginal plumose setae.

\section{Carapace (Figure 1A)}

Smooth, supraorbital spines absent, orbit feebly developed, without post orbital ridge, inferior orbital angle subacute, without inner flange, antennal spine acute, marginal, exceeding inferior orbital angle, hepatic spine absent, branchiostegal suture absent, branchiostegal spine acute, subequal to antennal spine, postmarginal, below and posterior to antennal spine, tip not reaching anterior carapace margin, anterolateral angle of branchiostegite broadly obtuse, ventral margin nonsetose.

\section{Abdomen (Figure 1D)}

Third tergite slightly posterodorsally produced, fifth segment about 0.65 of sixth segment length, sixth segment 1.6 times longer 
than deep, posterolateral angle acute, posteroventral angle acute, plumose setae ventrally; pleura of first three segments broadly rounded, fourth posteriorly produced, rounded, fifth produced, angular, posteroventrally acute, ventrally setose

\section{Telson (Figure 1H)}

About 0.9 of CL, 1.4 times sixth andominal segment length, 2.5 times longer than anterior width, lateral margins sublinear, posteriorly convergent, dorsally with 2 pairs of small subequal dorsolateral spines, about 0.1 of telson length, at 0.4 and 0.65 of telson length, posterior margin (Figure $4 \mathrm{G}$ ) about 0.4 of anterior margin width, with long slender apical point, about 0.7 of posterior telson width, 0.1 of telson length, far exceeding tips of lateral spines, with pair of anterodorsal setae, lateral spines similar to dorsal spines, medial spines well developed, subventral, about 0.33 of telson length, with pair of long slender plumose subventral submedian setae.

\section{Antennule (Figure 1E)}

Peduncle reaching to about 0.75 of the rostral length; proximal segment about 2.3 times longer than wide, medial margin with plumose setae, with strong acute ventromedial tooth at 0.5 of length, lateral margin feebly convex, with stout distolateral tooth reaching to about midlength of intermediate peduncular segment, anterolateral margin (Figure 4A) moderately produced, bluntly angular, with numerous plumose setae which extend along the subventral lateral border, stylocerite slender, acute, reaching to about 0.55 of segment length, statocyst with granular statolith; intermediate segment about 0.33 of proximal segment length, 1.6 times longer than wide, medial margin laminar, margins with plumose setae, distal segment subequal to intermediate segment length, 2.0 times longer than wide, upper flagellum biramous with proximal 5-6 segments of rami fused, short ramus with $7-8$ segments, with about 21 groups of aesthetascs on 10 distal segments, lower ramus slender, filiform, about 36 segments, lower flagellum slender, filiform, about 33 segments, 0.8 of longer free ramus of upper flagellum.

\section{Antenna (Figure 1F)}

Basicerite with small acute lateral tooth; ischiocerite and merocerite normal, carpocerite reaching to about 0.33 of scaphocerite length, subcylindrical, 3 times longer than wide; scaphocerite about 4 times longer than proximal width, lamella broad, tapering feebly distally, bluntly angular distally, lateral margin slightly concave, with strong tooth (Figure 4B) distally, not exceeding distal margin of lamella.
Eye (Figure 1G)

Cornea globular, about 0.25 of CL, black, with well developed accessory pigment spot, stalk subequal to corneal diameter, 1.2 times longer than central width. Ophthalmic somite with small blunt angular median process.

\section{Mandible (Figure 2A)}

Corpus large, stout, with long slender 3segmented palp distolaterally (Figure 4C) proximal two segments short, subequal, together subequal to length of subcylindrical setose terminal segment; molar process short, stout, subcylindrical, distally truncate, with 4 large blunt marginal teeth, scaphoid medially; incisor process normal, 3 teeth distally on right, 4 on left, central teeth smaller than outer teeth.

\section{Maxillula (Figure 2B)}

Palp (Figure 4D) bilobed, upper lobe with short slender simple seta, lower lobe with small ventral tubercule with minute terminal uncinate setule; upper lacinia broad, distally obliquely truncate with numerous short simple spines and setae distally; lower lacinia short, subcylindrical, tapering, distally truncate, with numerous feebly spiniform setae distally and ventrally.

\section{Maxilla (Figure 2C)}

Basal endite well developed, bilobed, lobes short, subequal, with numerous short simple setae distally; coxal endite obsolete, medial margin sublinear; palp short, non-setose; scaphognathite small, 3 times longer than central width.

\section{First maxilliped (Figure 2D)}

Basal endite large, broad, distally rounded, with numerous long simple marginal setae distomedially; coxal endite distinct, simple, medially convex with 4 very long setulose setae distomedially; palp short, simple, with single short plumose seta distally; exopod well developed, with large caridean lobe, ramus slender, with numerous plumose setae distally, epipod large, feebly bilobed, distal lobe much larger than proximal.

\section{Second maxilliped (Figure $2 \mathrm{E}$ )}

Of normal form, dactylar segment 3.5 times longer than broad, with numerous robust serrulate spines medially, propodal segment broad, distally rounded, feebly medially produced, with simple setae and spines distomedially; carpus acutely produced medially; ischiomerus and basis normal; exopod well developed, flagellum slender with numerous plumose setae distally, coxa broadly rounded medially, without ventral process, with several long simple setae medially, with small 

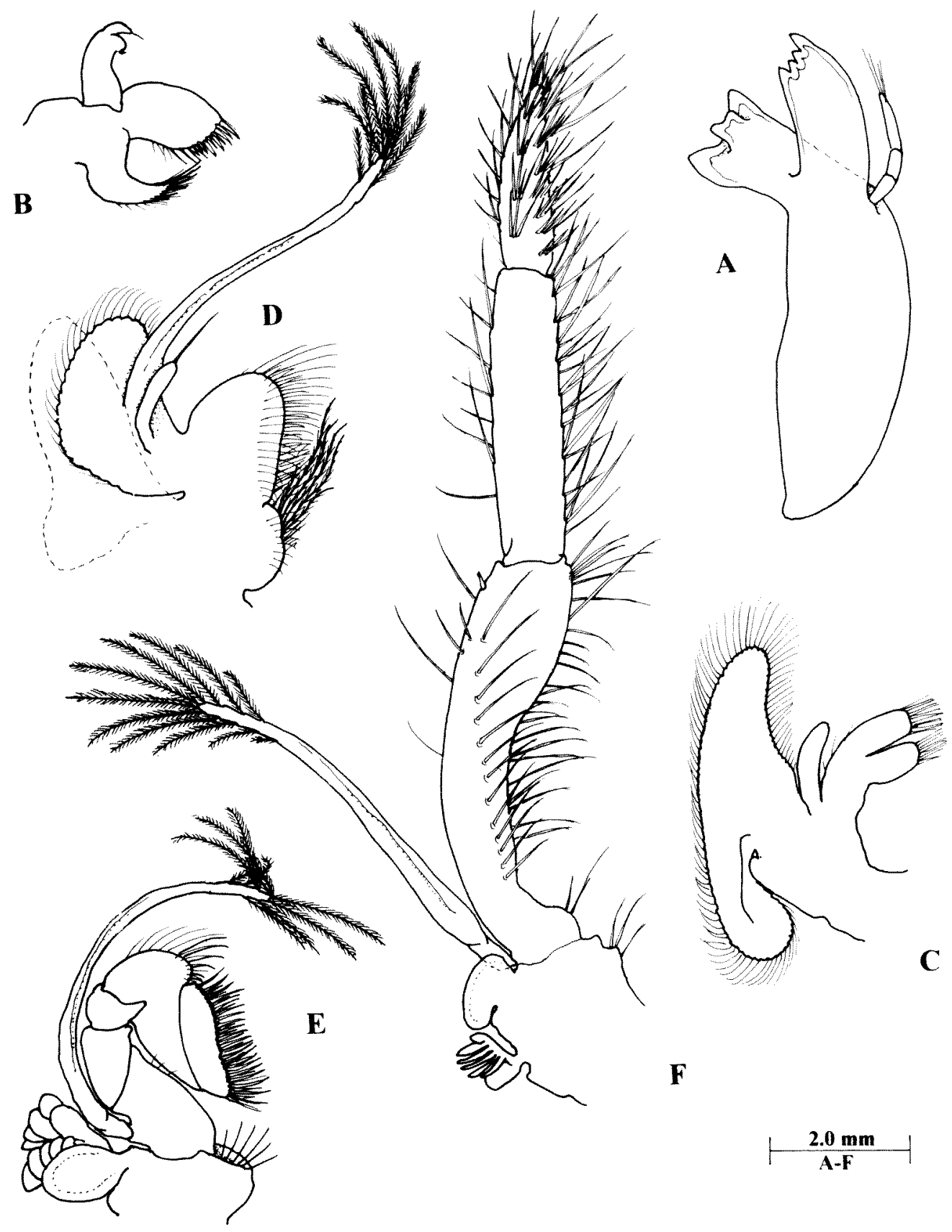

Figure 2 Leander manningi sp. nov., female holotype, Cockburn Sound, C28204. A, mandible (left). B, maxillula (right). $C$, maxilla. D, first maxilliped. E, second maxilliped. F, third maxilliped.

rounded epipod laterally with larger multilamellar podobranch.

\section{Third maxilliped (Figure 2F)}

Extending distally to exceed carpocerite by about half terminal segment length; endopod with ischiomerus completely fused with basis, combined segment about 4.5 times longer than distal width, bowed ventrally, expanded, twisted and flattened distally, distolateral angle with single small spine, medial margin with numerous long simple spiniform setae, similar setae present laterally; penultimate segment about 0.75 of antepenultimate segment length, subcylindrical, 4.5 times longer than wide, medial margin with numerous long simple spiniform setae, fewer on lateral margin; terminal segment 0.6 of antepenultimate segment length, 5.0 times longer than basal width, tapering distally, with short stout simple spine distally, with 8 transverse rows of serrulate spines ventromedially, longer simple spiniform setae distally and medially; exopod as in second 
maxilliped; coxa not medially produced, sparsely spinulate, with oval lateral plate; single small well developed multi-lamellar arthrobranch laterally.

\section{Epistome}

Anteriorly vertically angulate, without ventral beak.

\section{Thoracic sternites}

Fourth thoracic sternite with small short acute median process. Other sternites unarmed.

\section{First pereiopods (Figure $3 \mathrm{~A}$ )}

Normal, extending about level of distal antennular peduncle; chela (Figure 3B) with palm oval in section, slightly compressed, about 1.9 times longer than deep, with 5 rows of serrulate setae proximoventrally, fingers slender, simple, tapering to small hooked tips, lateral entire laminar cutting edge distinct over distal half, obsolete proximally, with sparse groups of simple and serrulate setae; carpus about 1.4 times chela length, 5.5 times longer than distal width, tapering proximally, unarmed, with 4-5 serrulate spines distoventrally; merus about 0.85 of carpus length, 5.5 times longer than central width, greatest width at half length, unarmed; ischium 0.55 of carpus length, 3.2 times longer than distal width, compressed distally, obliquely tapered proximally, with numerous long simple setae along ventral margin; basis about 0.3 of chela length, ventrally biconvex with long simple setae; coxa normal, with small setose distoventral process.

\section{Second pereiopod (Figure 3C)}

Subequal, similar, exceeding carpocerite by three fourths of carpus, scaphocerite by about length of fingers (in small female specimen), chela (Figure 3D) about 1.05 of CL, palm smooth, subcylindrical, slightly swollen centrally, 3.0 times longer than deep, fingers (Figure 3E) 0.88 of palm length, similar, with small simple hooked tips, cutting edges sharp, entire over distal three-fourths, sparsely setose, dactylus 6.4 times longer than proximal depth, with single small recurved acute tooth at 0.25 of length (Figure $4 \mathrm{E}$ ), fixed finger similar, smaller tooth at 0.2 of length; carpus 0.87 of chela length, 1.5 times palm length, 5.9 times longer than distal width, tapering proximally, slightly expanded distally, unarmed; merus 0.68 of chela length, 6.2 times longer than central width, subuniform, unarmed; ischium 0.6 of chela length 6.0 times longer than distal width, unarmed; basis and coxa normal.

\section{Third to fifth pereiopods (Figure $3 F$ )}

Third pereiopod of normal form, neither robust nor slender, exceeding carpocerite by distal half of propod, reaching to about distal margin of intermediate segment of antennular peduncle, dactyl simple (Figure $4 \mathrm{~F}$ ) about 0.42 of propod length, 5.2 times longer than basal width, strongly compressed, acute, unguis feebly defined, dorsal margin convex, ventral margin feebly concave, laminar, entire, with 3 spiniform setae at about 0.75 dorsal margin length, sensory setae present distally medially and laterally; propod (Figure 3G) 9.0 times longer than wide, uniform, with pair of distoventral spines, subequal to propod width (one missing in Figure 4F), 5 spiniform setae distodorsally, 4 single spines of decreasing size proximally along ventral border; carpus about 0.5 of propod length, 4.2 times longer than distal width, unarmed; merus 1.1 times propod length, 8.5 times longer than width, unarmed; ischium subequal to carpus length, 0.55 of propod length, unarmed; basis and coxa normal. Fourth and fifth pereiopods similar, fifth propod with normal distoventral spines and numerous serrulate ventral spines.

\section{Pleopods}

Male first pleopod (Figure $3 \mathrm{H}$ ) with basipodite 2.6 times longer than wide, distolateral angle acute, exopod subequal to basipodite length, 4.5 times longer than width, endopod (Figure 4I) 0.65 of exopod length, uniform, four times longer than wide, lateral margin feebly convex, with short plumose setae distally, distal margin similar, rounded, medial margin feebly concave, proximal third with four long plumose setae, middle third with four short curved spinules, distal third with short plumose setae, without appendix interna. Second pleopod (Figure 3I) with basipodite 1.1 times first pleopod basipodite length, 2.6 times longer than width, distolateral angle acute; exopod 1.1 times basipodite length, 4.2 times longer than width; endopod 0.9 of exopod length, 5.0 times longer than width, with appendices (Figure 4J) arising at 0.33 of medial margin length, appendix masculina slender, subcylindrical, slightly swollen distally, about 10 times longer than distal width, with numerous long slender simple spines along ventral surface and distolateral margin to tip, longest spines terminal, about 0.45 of appendix length, reaching almost to endopod end; appendix interna normal, reaching to about 0.6 of appendix masculina length, with few cincinnuli medially. Female first pleopod with endopod about 0.33 of exopod length, without spinules on central third of medial margin.

\section{Uropod (Figure 1I)}

Protopodite normal, posterolateral angle acute; exopod distinctly exceeding posterior end of telson, to about tip of submedian spines, with lateral margin straight, with small acute tooth distally (Figure $4 \mathrm{H}$ ), longer, more slender spine medially, 3.0 times longer than width, broadly rounded 


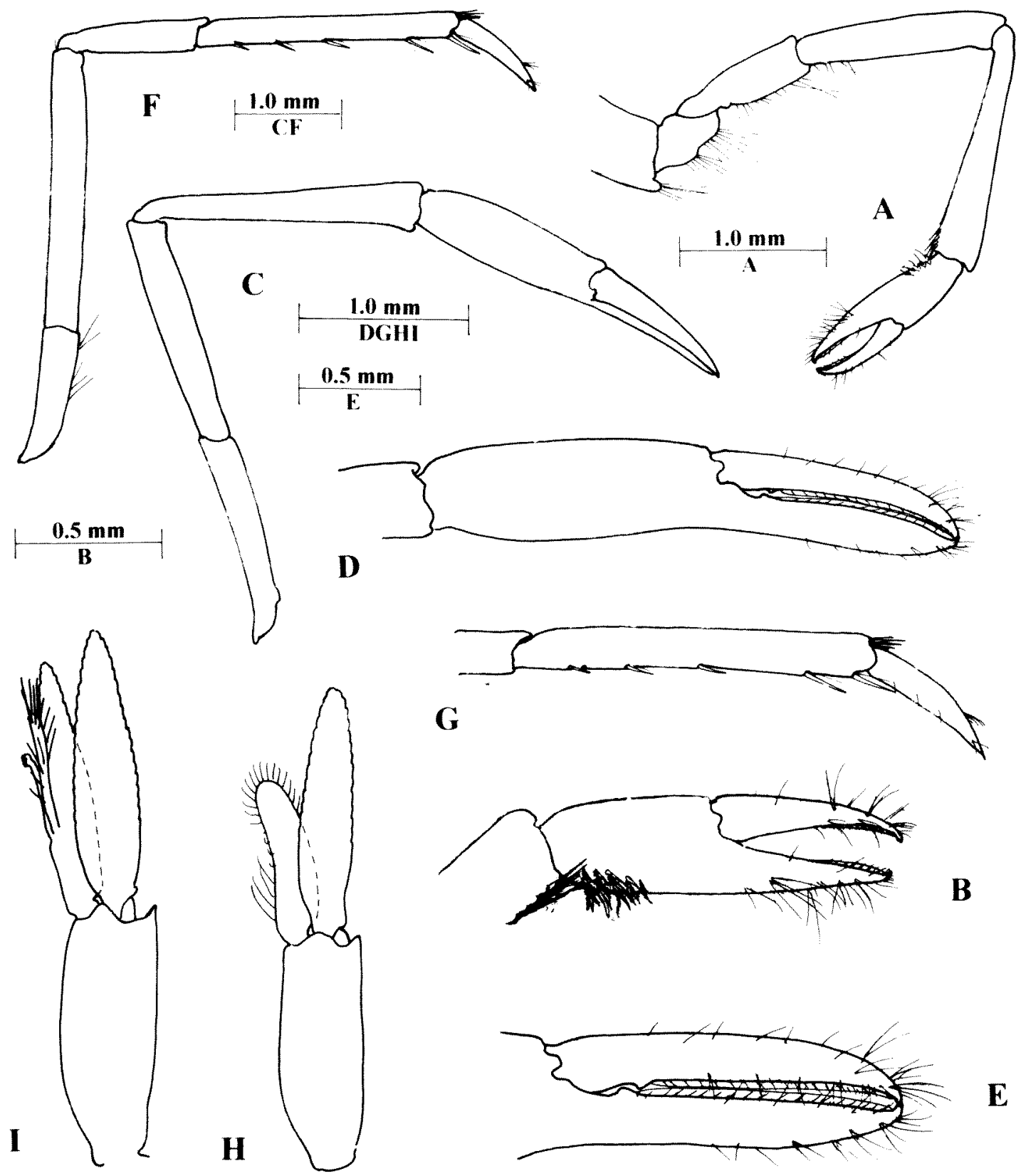

Figure 3 Leander manningi sp. nov., female holotype, Cockburn Sound, C28204. A, first pereiopod. B, same, chela. C, second pereiopod. D, same, chela. E, same, fingers. F, third pereiopod. G, same, propod and dactyl. Male paratype, C28205. H, first pleopod. I, second pleopod.

distally, with submarginal row of short setae dorsodistolaterally; endopod about 0.9 of exopod length, 3.2 times longer than wide.

\section{Measurements (mm's)}

Holotype: carapace length $3.15 \mathrm{~mm}$, carapace and rostrum $7.5 \mathrm{~mm}$, total body length (approx.) $18 \mathrm{~mm}$, second pereiopod chela $3.25 \mathrm{~mm}$. Largest paratype male, CL $4.7 \mathrm{~mm}$.

\section{Colour pattern}

Unknown.

\section{Habitat}

The specimens were collected from scrapings of marine harbour piles.

\section{Bathymetric range}

$0.5-7.0 \mathrm{~m}$.

\section{Etymology}

The species is named in honour of the late $\mathrm{Dr}$ Raymond B. Manning, who, in 1961, re-described Leander paulensis (Ortmann). 


\section{Distribution}

Type locality: Kwinana, Cockburn Sound, Western Australia.

\section{Systematic Position}

Closely related to Leander paulensis (Ortmann) and

L. tenuirostris (Say). May be distinguished by: -

1. Smaller number of dorsal rostral teeth, usually 9 (10-14 in L. paulensis, 8-14 in L. tenuicornis).

2. Anterior border of proximal segment of antennal peduncle feebly produced, far exceeded by distolateral tooth (distinctly produced in L. paulensis, not produced, confluent with elongate lateral tooth in $L$. tenuicornis).

3. Scaphocerite distally broad, with lamella exceeding distolateral tooth. (distally attenuated, with distolateral tooth distinctly exceeding lamella in L. paulensis)

4. First pereiopd with fingers subequal to palm (much longer than palm in L. tenuicornis, similar in L. paulensis).

5. Second pereiopod with palm not swollen (palm swollen in L. tenuicornis), with fingers shorter than palm length (longer in L. tenuicornis, similar in L. paulensis), cutting edge of dactyl with single small acute tooth proximally (2 small rounded teeth in $L$. paulensis, single small tooth in males in L. tenuicornis); carpus distinctly longer than palm and merus (of similar length to palm and shorter than merus in L. paulensis).

6. Comparatively short stout dactylus on ambulatory pereiopods, about 5 times longer than basal width, with sharp laminar ventral margin (about 10 times longer than basal width in L. paulensis, with obsolete ventral lamina).

\section{Remarks}

The specimens are unfortunately not in a good state and of the five specimens only two have a fully developed second pereiopod preserved (one specimen has both second pereiopods in an early stage of regeneration). The largest female (WAM $\mathrm{C} 28206 \mathrm{CL} 4.8 \mathrm{~mm}$ ) lacks most of the rostrum and has only one attached first pereiopod and both detached fifth pereiopods. The specimen (WAM C28204 CL 3.15) with a single second pereiopod and an intact rostrum is selected as the holotype. The smallest specimen (WAM C28205 CL 2.4) has both second pereiopods, with the chelae about 0.33 of the CL: the second pleopod has a rudimentary spineless appendix masculina. Only a single arthrobranch was observed on the third maxilliped in the dissected specimen, but a second may have been lost or destroyed during dissection.

Leander manningi differs from the diagnosis of the genus given in Chace and Bruce (1993). This states that in this genus the fourth thoracic sternite is unarmed and that an appendix interna is present on the male first pleopod. In L. manningi a small median process is present on the fourth thoracic sternite and the endopod of the male first pleopod lacks an appendix interna. However, a medial sternal process is present on the fourth thoracic sternite in $L$. plumosus, although this species does have an appendix interna on the male first pleopodal endopod (Bruce, 1994). Holthuis (1950a) confirms the presence of an appendix interna on the male first pleopod in L. tenuicornis and Ramos-Porto (1986) in L. paulensis. The situation in L. kempi was not reported by Holthuis (1950b) as all specimens were female. These discrepancies are not sufficient to prevent the inclusion of L. manningi in the genus Leander. Although not previously reported it may be noted that no sternal process can be discerned on the fourth thoracic sternite in $L$. paulensis and that the distoventral processes of the first pereiopod coxae are noticeably well developed. The Siboga paratypes of $L$. kempi have been re-examined in this study. Holthuis (1950b) reported that the carapace "is smooth, though short and rather stiff hairs often are scattered over its surface" and the "abdomen smooth, similar hairs as on the carapace present here, they are even more numerous especially on the posterior segments", and "The pubescence of the body of L. kempi, especially the abdomen, is not observed in L. tenuirostris". No trace of these setae can now be detected in these specimens and the body is completely glabrous, as in the other species of the genus other than L. plumosus. The larger ovigerous specimen has a CL of $9.1 \mathrm{~mm}$, and the fourth thoracic sternite bears a small short conical median process. The ventral rostral border also bears a double row of submarginal plumose setae, as in the other species of the genus, and not a single row.

The mouthparts of L. manningi in general closely resemble those of the type species of the genus, $L$. tenuicornis, as illustrated by Holthuis (1950a, 1950b). The main differences are: the palp is 3 segmented; the maxillula has the palp with a smaller setose upper lobe and a more blunt lower lobe with a small setiferous tubercle distoventrally, the lower lacinia is distinctly more slender; the maxilla has the basal endites subequal and similar, broader; first maxilliped with basal endite less elongate, coxal endite with 4 long plumose setae distomedially; second maxilliped with propodal segment shorter and broader, epipod smaller, podobranch less developed.

A revised diagnosis for the genus Leander is: palaemonine shrimps with rostrum well developed, lacking elevated basal crest; hepatic spine and branchiostegal suture absent, postmarginal branchiostegal spine present; mandible with palp; second pereiopods normally subequal, similar; ambulatory dactyls simple, shorter than propods. The species closely resemble Palaemon species, but these may generally be distinguished by the 


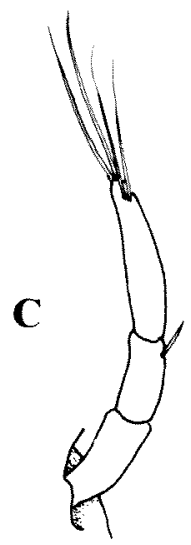

H
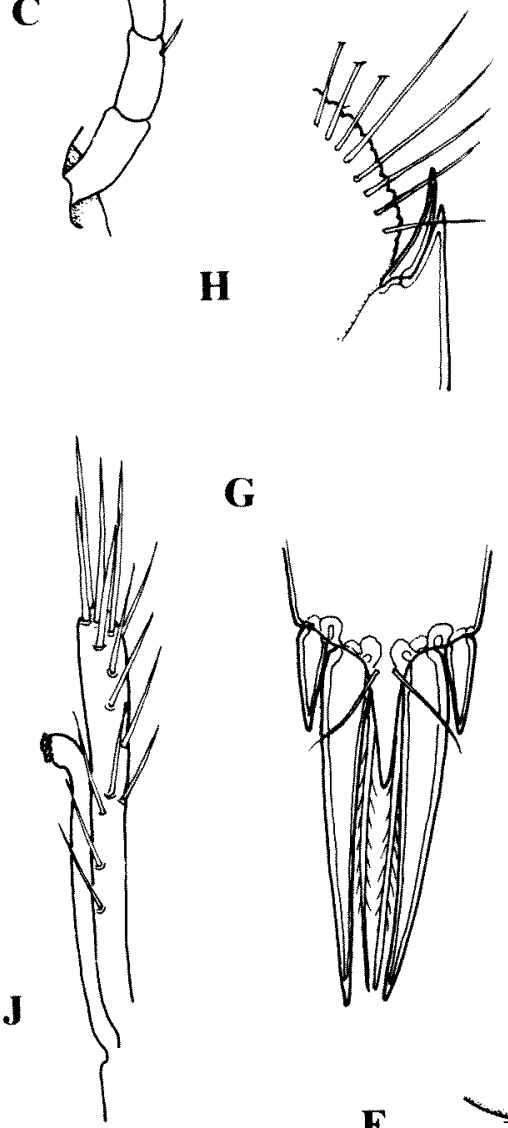

$\mathbf{F}$

G

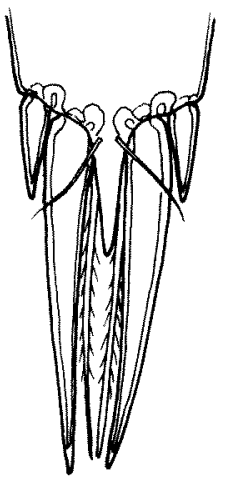

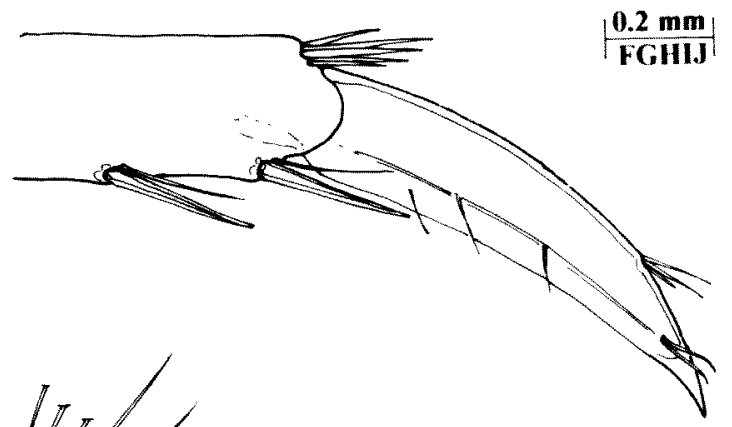
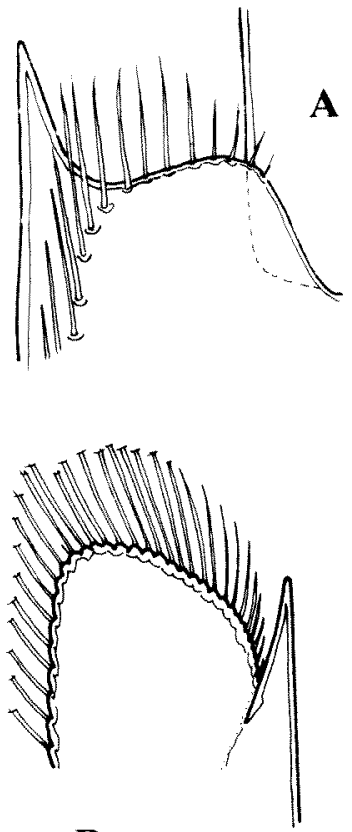

B

I

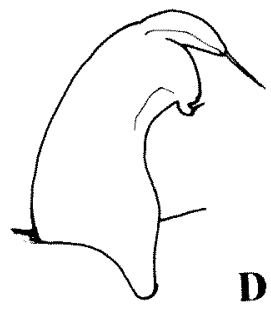

A

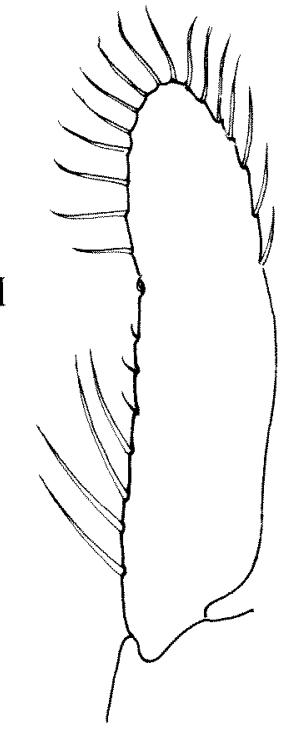

E

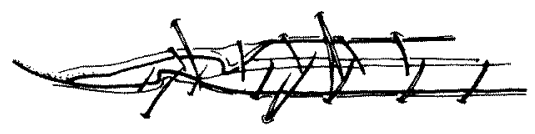

\begin{tabular}{|l|l}
$0.2 \mathrm{~mm}$ \\
$\mathrm{ACDE}$
\end{tabular}

D

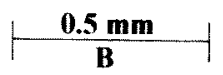

Figure 4 Leander manningi sp. nov., female holotype, Cockburn Sound, C28204. A, proximal antennal segment, distolateral margin. B, scaphocerite, distal margin. C, mandibular palp. D, maxillula, palp. E, second pereiopod, proximal cutting edges of fingers. $F$, third pereiopod, dactyl and distal propod. G, posterior telson margin. $\mathrm{H}$, uropod, distolateral exopod. Male paratype, C28205. I, first pleopod, endopod. J, second pleopod, endopod, appendix masculina and appendix interna.

presence of a distinct branchiostegal suture and generally a marginal branchiostegal spine. In the type species of the genus $P$. adspersus Rathke it is submarginal.

The figures of $L$. tenuicornis provided by Ledoyer (1984) suggest that the fourth pleuron is more angular than in L. manningi or L. paulensis, and that the ventral border of the ambulatory propod is armed with a double row of ventral spines, not present in these species.

\section{Leander Demarest, 1849}

Leander E. Desmarest, 1849: 92. Type species:
Leander erraticus Desmarest, 1849, junior synonym of Palaemon tenuicornis Say, 1818, by original designation and monotypy. Gender masculine.

Key for the identification of Leander species.

1. Rostrum greatly exceeding carapace length ( $x$ 2.5 in males, $x 1.75$ in females); carpus of second pereiopod distinctly longer than chela; R. 2+9-10/9-12

Leander plumosus Bruce

- Rostrum not exceeding 1.5 times carapace length; carpus of second pereiopod shorter than or not greatly exceeding chela length .. 2 


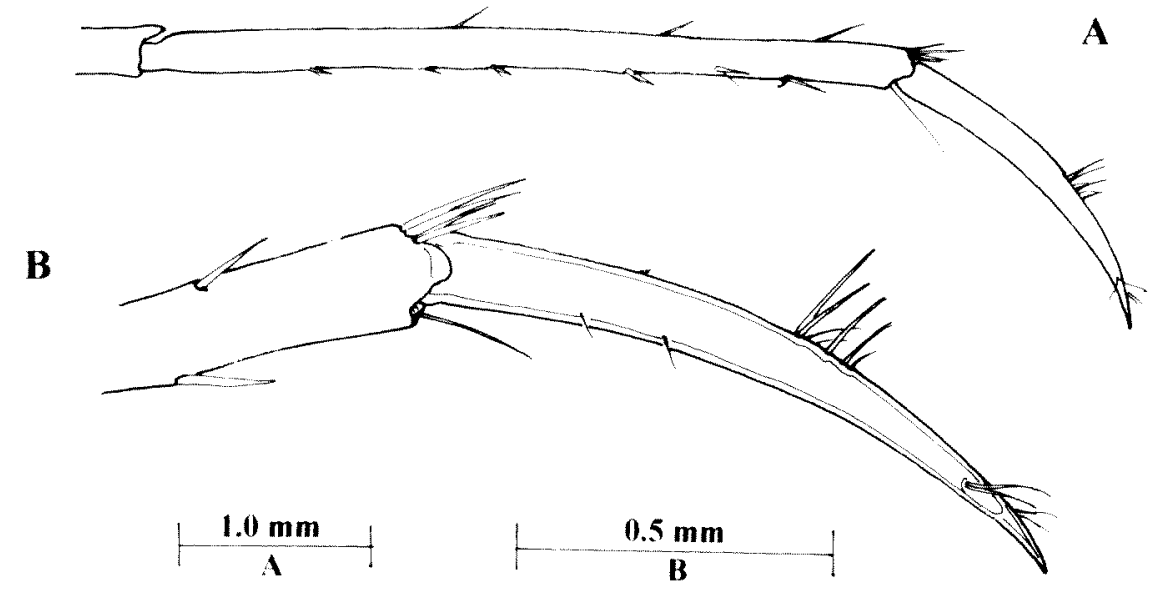

Figure 5 Leander paulensis (Ortmann), A, third pereiopod, propod and dactyl. B, same, distal propod and dactyl.

2. Ambulatory dactylus elongate, slender, ca 10 times longer than basal width; R. 3+8-11/5-7 Leander paulensis (Ortmann)

- Ambulatory dactyls robust, short, ca 5 times longer than basal width 3

3. Fifth pleuron posteroventrally rounded; $\mathrm{R}$. $2+10-12 / 5-7$ Leander kempi Holthuis

- Fifth pleuron posteroventrally acute 4

4. Anterolateral tooth of proximal segment of antennal peduncle reaching to level of half length margin of second segment, stylocerite not far exceeding half proximal segment length R. 2+7/5-6.. Leander manningi sp. nov.

Anterolateral tooth of proximal segment of antennal peduncle reaching to level of distal margin of second segment, stylocerite far exceeding half proximal segment length; $R$. 8-14/5-7 (rostrum sexually dimorphic)

Leander tenuicornis (Say)

The following species are known from the IndoWest Pacific region:

\section{Leander kempi Holthuis, 1950}

Leander kempi Holthuis, 1950b: 31-34, figure 3. Chace and Bruce, 1993: 6.

\section{Types}

1 ovig. female holotype, RMNH D 6858; 2 (1 ovig.female) paratypes ZMA, De. 102802;.

\section{Type localities}

Siboga station 121, Manado, Sulawesi, and Snellius station, Beo, Kepulaun Talaud, Indonesia.

Bathymetric range

To $55 \mathrm{~m}$ (Holthuis, $1950 \mathrm{~b})$.

\section{Distribution}

Indonesia: Known from the original description only, from Menado, Sulawesi, and Beo, Kepulauan Talaud.

\section{Remarks}

In the original description of this species, Holthuis (1950b) did not designate type material. This was done by Fransen, Holthuis and Adema (1997), in which the Talaud Islands specimen was chosen as the holotype.

\section{Leander manningi sp. nov.}

See above.

\section{Leander plumosus Bruce, 1994}

Restricted synonmy

Leander plumosus Bruce, 1990, 62-62; 1994: 39-48, figures $1-5,6 \mathrm{AB}$, plate 2 .

\section{Types}

Holotype female, NTM Cr.8567A; paratype, dissected male, NTM Cr.008567B.

\section{Type locality}

Ari Atoll, Maldive Islands.

\section{Bathymetric range}

From 3m (Minemizu, 2000); $7 \mathrm{~m}$ (Bruce, 1994, 1996;

Okuno and Ono, 1998); 15m (Gosliner et al., 1996).

\section{Distribution}

Maldive Islands (Bruce, 1994). Indonesia: Bali, (Bruce, 1990; Steene, 1990; Debelius,1999); Flores (Debelius, 1999). Japan: Ryukyu Islands, Ishigaki Island, Yaeyama group, and Kerama Islands 


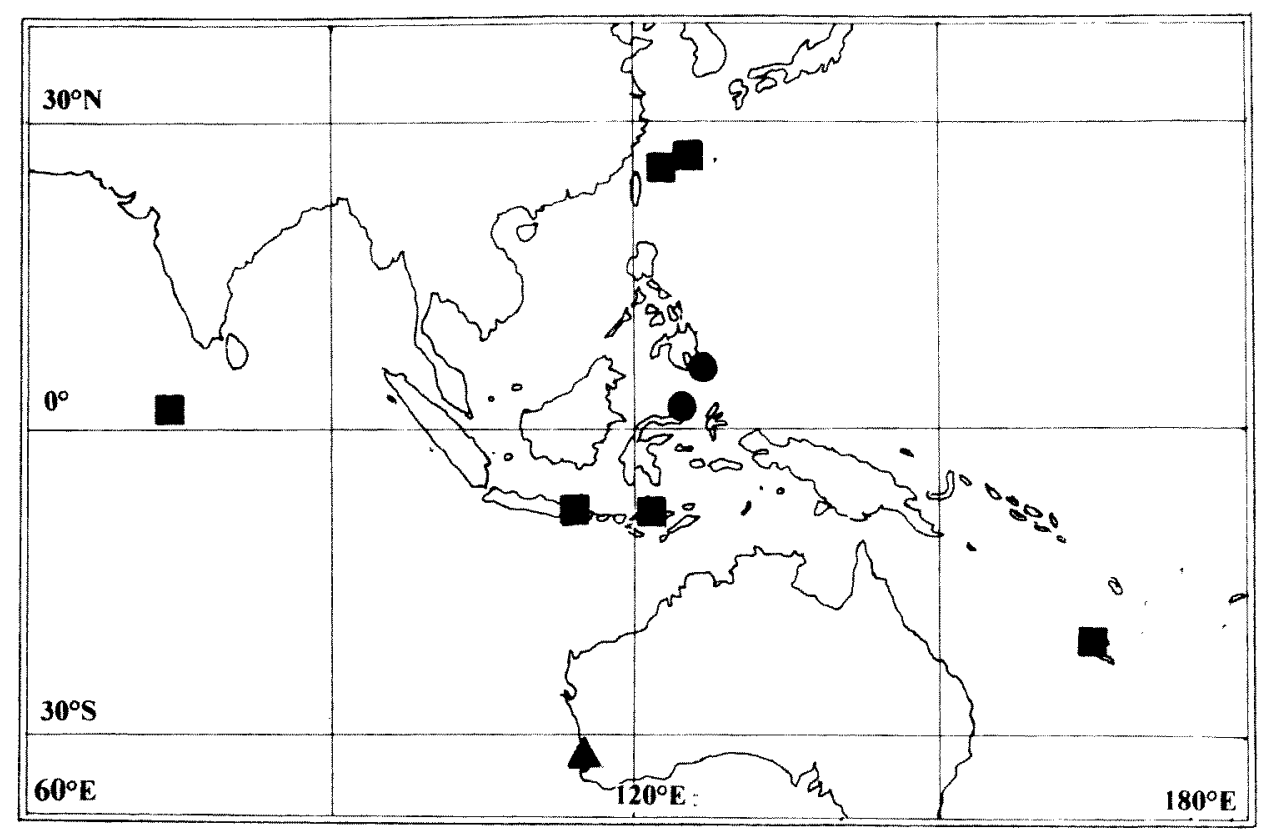

Figure 6 Distributions of Leander kempi (•), Leander plumosus ( $\mathbf{\square}$ ) and Leander manningi ( $\mathbf{\Delta}$ ).

(Okuno and Ono, 1998). New Caledonia: Senez Reef (Bruce, 1996).

\section{Restricted synonmy \\ Leander tenuicornis (Say, 1818)}

Palaemon tenuicomis Say, 1818: 249.

\section{Leander erraticus Desmarest, 1849: 92.}

Leander tenuicornis - Kingsley, 1978: 122. - Kemp, 1925: 302-304, figure 11. - Holthius, 1950a: 2628, figures $1-2 ; 1950 \mathrm{~b}$ : 155-167, pls 41, 42. Ledoyer, 1984: 25, figure 9. - Ramos-Porto, 1986: 13-16, figures 5-6. - Chace and Bruce, 1993: 6-7. - Holthuis, 1993: 108 figure 95.

\section{Types}

"The type specimens are preserved in the collection of the Academy of Natural Sciences at Philadelphia" (Holthuis, 1950), and are now reported as lost (Boyko, personal communication, 17 January 2001). Two syntypes, also can not now be located in the BMNH collections (M. Lowe, personal communication, 27 January 2001).

\section{Type Locality}

Newfoundland Banks.

\section{Bathymetric range}

Shallow water, in sea grass beds and algae, frequently in floating Sargassum.

\section{Distribution}

Widespread thoughout most tropical, subtropical and some temperate waters. From Atlantic: Newfoundland to Brazil; Mediterranean Sea. IndoWest Pacific: Red Sea to South Africa, east to Japan, Philippines, Caroline Islands, and New Zealand (Chace and Bruce, 1993). Numerous records from Australian waters. Not recorded from the Central Pacific east of Palau or the East Pacific region.

\section{Remarks}

The Falkland Islands record (Kemp, 1925) has never been verified. Kemp does not indicate the origin or present whereabouts of the specimens upon which this report is based. Holthuis (1952: 73), states "Miers (1876: 86) remarks that Palaemon affinis, which species is named Leander affinis by him, occurs on the Falklands. This is, however, very improbable since the species at present is known from New Zealand only. Miers's specimen may have been incorrectly labelled or misidentified. Leander tenuicornis (Say) for the first time has been reported from the Falkland Islands by Kemp (1925: $304)$. Since that time the species has no more been recorded from that region."

\section{ACKNOWLEDGEMENTS}

I am most grateful to Melissa Hewitt for the opportunity to report on this shrimp and to the Australian Biological Resources Study for their support. Dr C.H.J.M. Fransen kindly provided Brazilian specimens of Leander paulensis for comparative purposes and the holotype of Leander kempi for comparative purposes, and Dr D. Platvoet the paratypes of Leander kempi. Dr C. Hewitt provided details of the locality of capture. Dr John 
Short and Cédric d'Udekem d'Acoz also provided helpful information The collection of the L. manning $i$ specimens was part of the National Port Survey Program established by CSIRO Marine Research in conjunction with the Australian Association of Ports and Marine Authorities (AAPMA) and with the financial support of the Fremantle Port Authority, the Defence Estate Organisation (HMAS Stirling) and the Australian Quarantine and Inspection Service.

\section{REFERENCES}

Bruce, A.J. (1990). An unusual shrimp from Bali. Voice of Nature 79: 62-63.

Bruce, A.J. (1994). Leander plumosus sp. nov., a new palaemonine shrimp (Crustacea: Palaemonidae) from the Maldive Islands. The Beagle, Records of the Museums and Art Galleries of the Northern Territory 11: 39-51.

Bruce, A.J. (1996). Crustacea Decapoda: Palaemonid shrimps from the Indo-West Pacific region, mainly from New Caledonia. In: A. Crosnier (ed.), Résultats des Campagnes MUSORSTOM, 15. Mémoires du Muséum National d'Histoire Naturelle 168: 197-267.

Chace, F.A., Jr., and A.J. Bruce. (1993). The Caridean Shrimps (Crustacea: Decapoda) of the Albatross Philippine Expedition 1907-1910, Part 6: Superfamily Palaemonoidea. Smithsonian Contributions to Zoology 543: 1-252.

Debelius, H. (1999). Crustacea Guide of the World. IKAM Unterwasserarchiv, Frankfurt.

Desmarest, E. (1849). Description d'un nouveau genre de Crustacés de la section des Décapodes Macroures, famille des Salicoques, tribu des Palémoniens (Genre Leander). Annales de la Societé Entomologique de France (2) 7: 87-94.

Fransen, C.H.J.M., L.B Holthuis \& J.P.H.M Adema. (1997). Type-catalogue of the Decapod Crustacea in the collections of the National Natuurhistorisch Museum, with appendices of pre-1900 collectors and material. Zoologische Verhandelingen Leiden 311: 1-344.

Gosliner, T.M., D.W. Behrens and G.C. Williams. (1996). Coral reef animals of the Indo-West Pacific. Sea Challengers, Monteray

Haan, W. De. (1833-1850). Crustacea. In: Siebold, P.F.De. Fauna Japonica sive Descriptio animalium, quae in itinere per Japoniam, jussu et auspiciis superiorum, qui summum in India Batava Imperium tenent, suscepto, annis 1823-1830 collegit, notis, observationibus et adumbrationibus illustravit.

Holthuis, L.B. (1950a). A general Revision of the Palaemonidae (Crustacea Decapoda Natantia) of the Americas. II. The Subfamily Palaemonidae. Allan Hancock Foundation Publications, Occasional Papers 11: $1-396$
Holthuis, L.B. (1950b). The Decapoda of the Siboga Expedition. Part XI. The Palaemonidae collected by the Siboga and Snellius Expeditions with remarks on other species. I. Subfamily Palaemoninae. Siboga Expedition Monograph, 39.9: 1-268.

Holthuis, L.B. (1952). The Crustacea Decapoda Macrura of Chile. Lunds Universitets Arsskrift N. F. Avd. 2. Bd $47 \mathrm{Nr} 10$ / Kungl. Fysiografiska Sällskapets Handlingar N. F. Bd $62 \mathrm{Nr} 10$ )

Holthuis, L.B. (1993). The recent genera of the caridean and stenopodidean shrimps (Crustacea, Decapoda) with an appendix on the order Amphionidacea. Nationaal Natuurhistorisch Museum, Leiden.

Kemp, S. (1925). On various Caridea. Notes on Crustacea Decapoda in the Indian Museum. XVII. Records of the Indian Museum 27: 249-343.

Kingsley, J.S. (1878). Notes on the North American Caridea in the Museum of the Peabody Academy of Science at Salem, Mass. Proceedings of the Academy of Natural Sciences, Philadelphia 1878: 89-98.

Ledoyer, M. (1984). Les Caridea (Crustacea: Decapoda) des Herbiers de Phanérogames Marines de NouvelleCalédonie (Région de Nouméa). Zoologische Verhandelingen, Leiden. 211: 3-58.

Manning, R.B. (1961). A redescription of the palaemonid shrimp, Leander paulensis Ortmann, based on material from Florida. Bulletin of Marine Science 11 (4): 525536.

Miers, E.J. (1876). Catalogue of the stalk-eyed and sessile-eyed Crustacea of New Zealand. Publisher???

Minemizu, R. (2000). Marine decapod and stomatopod crustaceans mainly from Japan. Bun-ichi Sogo Shuppan, Co. Ltd., Tokyo.

Okuno, J. and A. Ono. (1998). First record of a palaemonine shrimp, Leander plumosus Bruce, 1994 from Japan (Crustacea: Decapoda: Palaemonidae). Journal of the Natural History Museum and Institute Chiba 5 (1): 35-39.

Ortmann, A. (1897). Os Camaröes da Agua Doce da America do Sul. Da Revista do Museu Paulista. 2: 173216

Ramos-Porto, M. (1986). Revisão das espécies do genêro Leander Desmarest que occurem no litoral brasiliero. Trabahlos Oceanographico Universidad Federal, Pernambuco 19: 7-26.

Say, T. (1817-1818). An account of the Crustacea of the United States. Journal of the Academy of Natural Sciences of Philadelphia 1 (1817): 57-80, 97-101, 151-169; (1818): 235-253, 313-319, 374-401, 423, 441, 445-458.

Steene, R. (1999). Coral Reefs: Nature's Richest Realm, Crawford House Press: Bathurst, Australia.

Manuscript received 13 February 2001; accepted 14 September 2001. 